\title{
Article
}

Doi 10.5943/sif/5/1/5

\section{Aspergillus gaarensis, a new addition to section Circumdati from soil of Lake El-Gaar in Wadi-El-Natron, Egypt}

\author{
Al-Bedak $\mathrm{OA}^{1 *}$ and Moubasher $\mathrm{AH}^{1,2}$ \\ ${ }^{1}$ Assiut University Mycological Centre (AUMC), Assiut University, Assiut 71511, Egypt \\ ${ }^{2}$ Department of Botany and Microbiology, Faculty of Science, Assiut University, Assiut, Egypt
}

Al-Bedak OA, Moubasher AH 2020 - Aspergillus gaarensis, a new addition to section Circumdati from soil of Lake El-Gaar in Wadi-El-Natron, Egypt. Studies in Fungi 5(1), 59-65, Doi 10.5943/sif/5/1/5

\begin{abstract}
In the present study, a novel fungus belonging to the genus Aspergillus section Circumdati was isolated from a cultivated soil sample close to El-Gaar lake in Wadi-El-Natron region, Egypt. Sequence of the internal transcribed spacer (ITS) gene of its DNA showed that the isolate differs from all known Aspergillus species in section Circumdati. The novel Aspergillus species is described here as Aspergillus gaarensis. Phenotypic characteristics and molecular data were applied to determine its novel taxonomic status. Both macro and micro characteristics of the novel species are presented in the current study.
\end{abstract}

Key words - ITS - new taxon - phylogeny - saline

\section{Introduction}

A large number of studies have demonstrated that molecular approaches based on DNA sequencing combined with traditional methods based on phenotypic features are the most accurate means of reliably characterizing species of the genus Aspergillus. In general, the genus Aspergillus, which is currently divided into seven subgenera, each of which is subdivided into sections, is analyzed at the molecular intersection level by means of the nuclear rRNA gene operon. Aspergillus species belonging to section Circumdati include very important members as they considered good producers of ochratoxin A (Van der Merwe et al. 1965, Ciegler 1972, Hesseltine et al. 1972), penicillic acid (Ciegler 1972), xanthomegnin, viomellein and vioxanthin (Robbers et al. 1978, Stack \& Mislivec 1978). These species are also used in the biotransformation's industry (Singh et al. 1968, Miski \& Davis 1988). During our mycological studies of extremophilic fungi in different habitats in Wadi-El-Natron region, Egypt (Ismail et al. 2017), we have collected several potentially new taxa including the strain described in the current study.

\section{Materials \& Methods}

\section{Sampling site}

Wadi-El-Natron is situated at $30^{\circ} 17^{\prime}$ and $30^{\circ} 38^{\prime} \mathrm{N}$ and $30^{\circ} 2^{\prime}$ and $30^{\circ} 30^{\prime} \mathrm{E}$ in the Western Desert adjacent to the Nile Delta of Egypt. It lies $23 \mathrm{~m}$ below the Mediterranean Sea level and $38 \mathrm{~m}$ below the water level of Rosetta branch of the Nile River (Ismail et al. 2017). Lake El-Gaar is about $1.9 \mathrm{~km}^{2}$ in the extreme north of the depression and it never dries up in the summer (Fig. 1). Soil sample was collected from a field cultivated with Guava close to El-Gaar lake. 


\section{Fungal isolation}

The novel Aspergillus species was isolated from one of the analyzed soil samples collected during Feb 2012, using dilution plate technique on 10 \% NaCl-Czapek’s agar (Ismail et al. 2017). Sterile plates, each containing $1 \mathrm{ml}$ of soil suspension of appropriate dilution and $20 \mathrm{ml}$ medium, were incubated for 15 days at $25^{\circ} \mathrm{C}$. The obtained strain was then purified and maintained as pure culture on malt extract agar slants (MEA, (Samson 2010) and deposited in the Culture Collection of Assiut University Mycological Centre with accession number AUMC 11046 and in the Egyptian Microbial Culture Collection Network with accession number EMCCN 2221.Sequence of the ITS gene was uploaded to GenBank with accession number MN648408 and description of the novel species was deposited in Mycobank with accession number MB 833223.
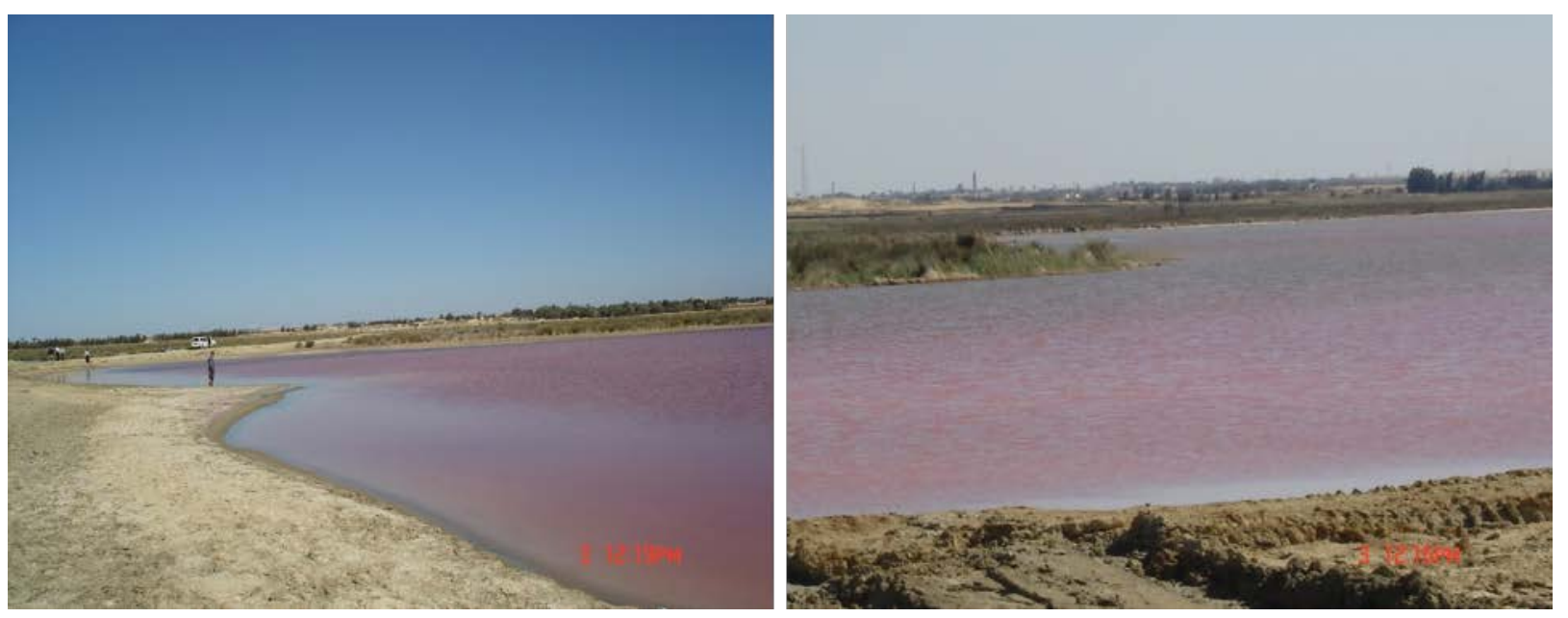

Fig. 1 - Reddish appearance of lake El-Gaar in Wadi-El-Natron where the new species was isolated

\section{Morphological studies}

Culture characteristics and growth rates were studied on yeast extract sucrose agar (YES, (Frisvad 1981), malt extract agar (MEA, (Samson 2010), Blakeslee's malt extract agar (MEAbl, (Blakeslee 1915), malt extract $20 \%$ sucrose agar ( $\mathrm{M}_{20} \mathrm{~S}$, (Samson 2010), M40 , Czapek's yeast Autolysate agar (CYA, (Pitt 1979), CYA with 20 \% sucrose agar (CY20S, (Klich 2002), Czapek’s agar (CZ, (Raper \& Fennel 1965), Creatine sucrose agar (CREA, (Frisvad 1981), urease enzyme (Paterson \& Bridge 1994), ammonium salt agar (mannitol agar, (Brayford \& Bridge 1989) and tannin sucrose agar (TAN, (Thrane 1986). Inoculations were made from spore suspension prepared in a $0.2 \%$ agar and $0.05 \%$ Tween 80 solution (Samson et al. 2014). Plates were inoculated in threepoint pattern using a micropipette and inoculum size of $1 \mu 1$ per spot. Unwrapped cultures were incubated in the dark reverse side up at $25^{\circ} \mathrm{C}$, with additional CYA plates incubated at $37^{\circ} \mathrm{C}$. Microscopic features on MEA were examined in lacto-phenol cotton blue.

\section{Molecular identification of the fungal isolate}

\section{DNA extraction}

Prior to DNA extraction, small piece of fungal mycelia of 7-day-old culture of A. gaarensis AUMC 11046 grown on MEA was collected and transferred to 2 ml-Eppendorf tube. DNA extraction was carried out according to the method of (Moubasher et al. 2019).

\section{PCR for rDNA and sequencing using ITS1 and ITS4 primers}

The PCR reaction was performed using SolGent EF-Taq. The universal primers ITS1 and ITS4 (White et al. 1990) were used for amplification of DNA. In the PCR tubes $1 \mu$ of DNA template, $1 \mu \mathrm{l} 2.5 \mathrm{mM}$ dNTP mix, 0.2 unit of Taq polymerase, $5 \mu \mathrm{l}$ of 10x complete buffer and 40 $\mu \mathrm{l}$ of sterile ddH2O, 10 pmol of ITS1 (5' TCC GTA GGT GAA CCT TGC GG 3') and ITS4 (5' 
TCC TCC GCT TAT TGA TAT GC 3') were added. Then the PCR amplification was carried out using the following sequence: one round of amplification consisting of denaturation at $95^{\circ} \mathrm{C}$ for $15 \mathrm{~min}$ followed by 30 cycles of denaturation at $95^{\circ} \mathrm{C}$ for $20 \mathrm{sec}$, annealing at $50^{\circ} \mathrm{C}$ for $40 \mathrm{sec}$ and extension at $72^{\circ} \mathrm{C}$ for $1 \mathrm{~min}$, with a final extension step of $72^{\circ} \mathrm{C}$ for $5 \mathrm{~min}$. The PCR products were then purified with the SolGent PCR Purification Kit-Ultra (SolGent, Daejeon, South Korea) prior to sequencing. The purified PCR products were confirmed on $1 \%$ agarose gel by electrophoresis using size marker. The bands were eluted and sequenced in the forward and reverse directions.

\section{Alignments and phylogenetic analysis}

Sequences of the novel species in the present study were assembled using SeqMan software (DNA star version 5.05). Published sequences for the closest matching strains including the available type materials were downloaded from GenBank. Assembled sequences of the new species and those downloaded from GenBank were aligned together using ClustalX (Thompson et al. 1997) and improved manually. The evolutionary history was inferred by using the Maximum Likelihood method and Tamura-Nei model (Tamura \& Nei 1993). The tree with the highest log likelihood $(-801.65)$ was obtained. The percentage of trees in which the associated taxa clustered together is shown next to the branches (Felsenstein 1985). Initial tree(s) for the heuristic search were obtained by applying the Neighbor-Joining method to a matrix of pairwise distances estimated using the Maximum Composite Likelihood (MCL) approach. A discrete Gamma distribution was used to model evolutionary rate differences among sites ( 5 categories $(+G$, parameter $=0.5746)$ ). The rate variation model allowed for some sites to be evolutionarily invariable ([+I], 46.09\% sites). The tree is drawn to scale, with branch lengths measured in the number of substitutions per site. Codon positions included were 1st+2nd+3rd+Noncoding. All positions containing gaps and missing data were eliminated (complete deletion option). Evolutionary analyses were conducted in MEGA X version 10.1.6 (Kumar et al. 2018).

\section{Results}

\section{Phylogenetic analyses}

The ITS dataset comprised 25 sequences, of which 24 are Aspergillus species belonging to section Circumdati including the available type strains published in GenBank, in addition to the sequence of the novel species obtained in the current study. There was a total of 380 positions in the final dataset. Maximum likelihood analysis yielded one tree (Fig. 2), in which A. gaarensis AUMC 11046 was consistently located in a distinct branch indicating its novelty. A megablast search using the ITS sequence of the new species revealed that the closest matches in GenBank nucleotide database were A. ochraceopetaliformis CBS 123.55 [(GenBank MH857406; Identities 556/605 (91.9\%), 42 gaps (6 \%); $98.0 \%$ coverage of the ITS gene with interspecific difference of 49 nucleotides], A. pulvericola CBS 137327 [(GenBank NR135453; Identities 543/587 (92.5 \%), 42 gaps (7\%); $95.0 \%$ coverage of the ITS gene with interspecific difference of 44 nucleotides)], $A$. insulicola NRRL 6138 [(GenBank NR135391; Identities 536/578 (92.73 \%), 38 gaps (6 \%); 93.0 coverage of the ITS gene with interspecific difference of 42 nucleotides)] and $A$. ochraceopetaliformis NRRL 4752 [(GenBank NR135390; Identities 530/575 (92.17 \%), 42 gaps (7 $\%) ; 93.0 \%$ coverage of the ITS gene with interspecific difference of 45 nucleotides)].

\section{Taxonomy}

Aspergillus gaarensis Al-Bedak O.A. \& Moubasher A.H., sp. nov. Figs 3-4

GenBank accession number (ITS): MN648408; Mycobank number: MB833223

Typification: EGYPT. Wadi-El-Natron: Lake El-Gaar, isolated from soil sample, 2012, Osama A. Al-Bedak (holotype AUMC 11046 = EMCCN 2221).

Etymology: Named after Lake El-Gaar, Wadi-El-Natron, Egypt, from which the fungus was isolated. 
Macroscopic and microscopic characteristics - Conidiophores pale brown to brown, rough, 200-600 × 5-8 $\mu \mathrm{m}(\bar{x}=400 \times 6.5 \mu \mathrm{m})$. Conidial heads radiate, up to $80 \mu \mathrm{m}$ width. Vesicles globose, 20-40 $\mu \mathrm{m}$. Metulae 8-13 $\mu \mathrm{m}$. Phialides 6-10 $\mu \mathrm{m}$. Conidia globose, subglobose, 2.5-3.0 $\times$ 2.5-3.0 $\mu \mathrm{m}(\bar{x}=2.75 \times 2.75 \mu \mathrm{m})$. Sclerotia and ascomata not observed (Fig. 3).

Colonies on MEA attaining $40-48 \mathrm{~mm}$ in diameter after 7 days at $25^{\circ} \mathrm{C}$, floccose, raised in the center, yellowish-white to pale yellow (3A2-3); sporulation abundant; margin entire; soluble pigments and exudates absent; reverse drab to hair brown (5E3-4) in the center, paler towards the margin. Colonies on CYA attaining a diameter of 36-46 mm after 7 days at $25^{\circ} \mathrm{C}$, floccose, radially sulcate, the colony center raised, wine yellow, dull yellow, ivory, platinum blonde, sand (3B34B3); margin entire, marble white, alabaster, orange grey (5B2); sporulation abundant, reverse topaz to Pompeian yellow (5C5-6); sclerotia absent. On Cz after 7 days at $25^{\circ} \mathrm{C}$, colonies attaining 30-35 mm in diameter, centrally floccose, white, yellowish-white to pale yellow (3A1-2/2A2-3); sporulation light; margin entire; soluble pigments and exudates absent; reverse yellowish-white (2A2/3A2) (Fig. 4). The colony diameter of A. gaarensis on the remaining media can be summarized in Table 1.

In the phylogenetic analysis, there was a total of 380 positions in the final dataset. Maximum likelihood analysis yielded one tree, in which A. gaarensis AUMC 11046 was consistently located in a distinct branch indicating its novelty. A megablast search within GenBank nucleotide database using the ITS sequence of the new species revealed that the closest matching species were $A$. ochraceopetaliformis CBS 123.55, A. pulvericola CBS 137327, A. insulicola NRRL 6138 and A. ochraceopetaliformis NRRL 4752. The interspecific difference between the new species and the most similar species in GenBank ranged from 42 nucleotides in A. insulicola NRRL 6138, 44 nucleotides in A. pulvericola CBS 137327, 45 nucleotides in A. ochraceopetaliformis NRRL 4752 and 49 nucleotides in A. ochraceopetaliformis CBS 123.55.

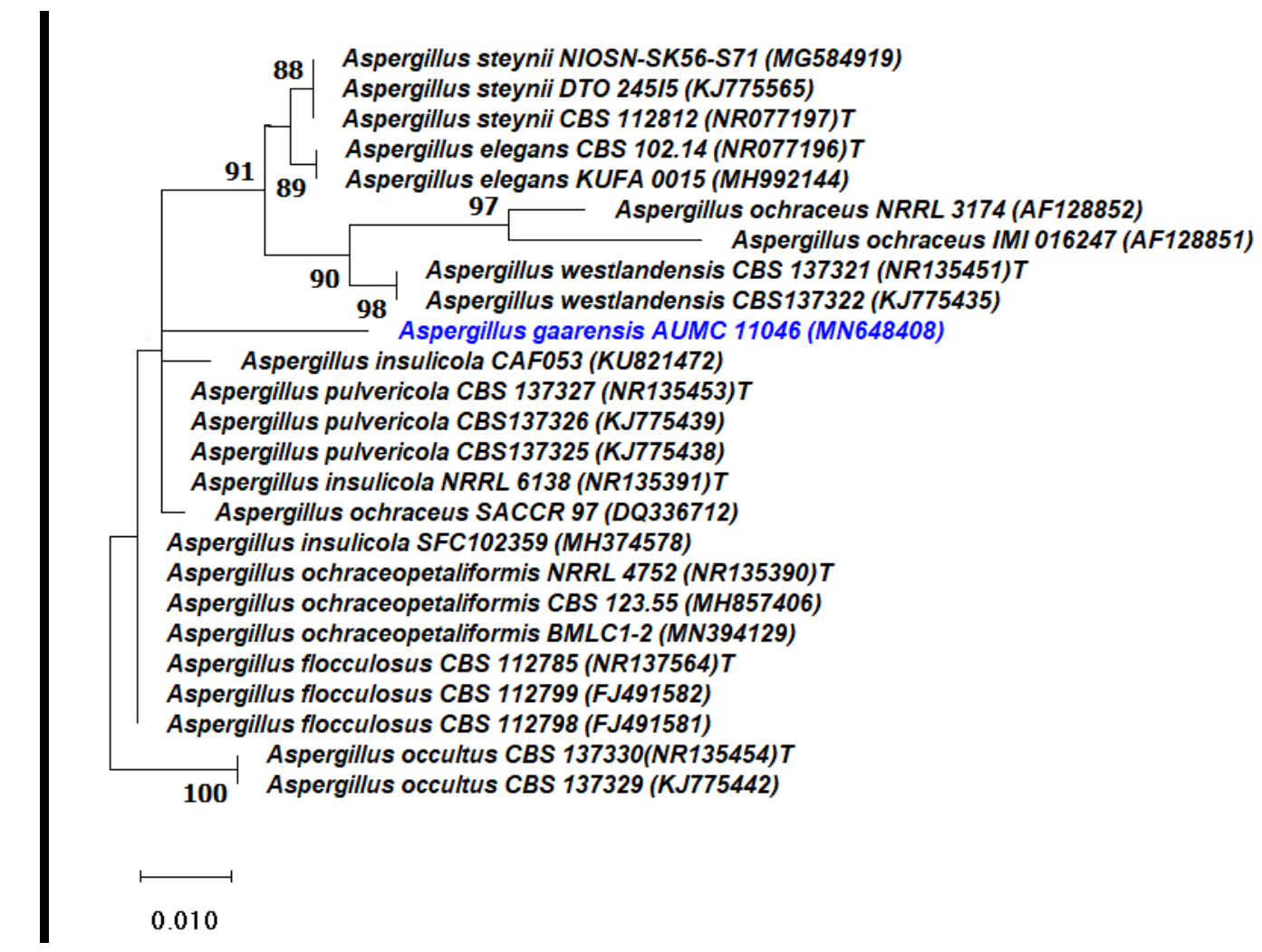

Fig. 2 - Maximum Likelihood phylogenetic tree of A. gaarensis sp. nov. strain AUMC 11046 aligned with other related Aspergillus species in section Circumdati based on the ITS gene sequences. GenBank accession numbers in parentheses. Sequence of the new species is in blue color. The numbers near the branches are the bootstrap values (100 pseudoreplicates). Values $<70$ $\%$ are not shown. Bar 0.01 substitutions per nucleotide. The tree is rooted to A. occultus. 


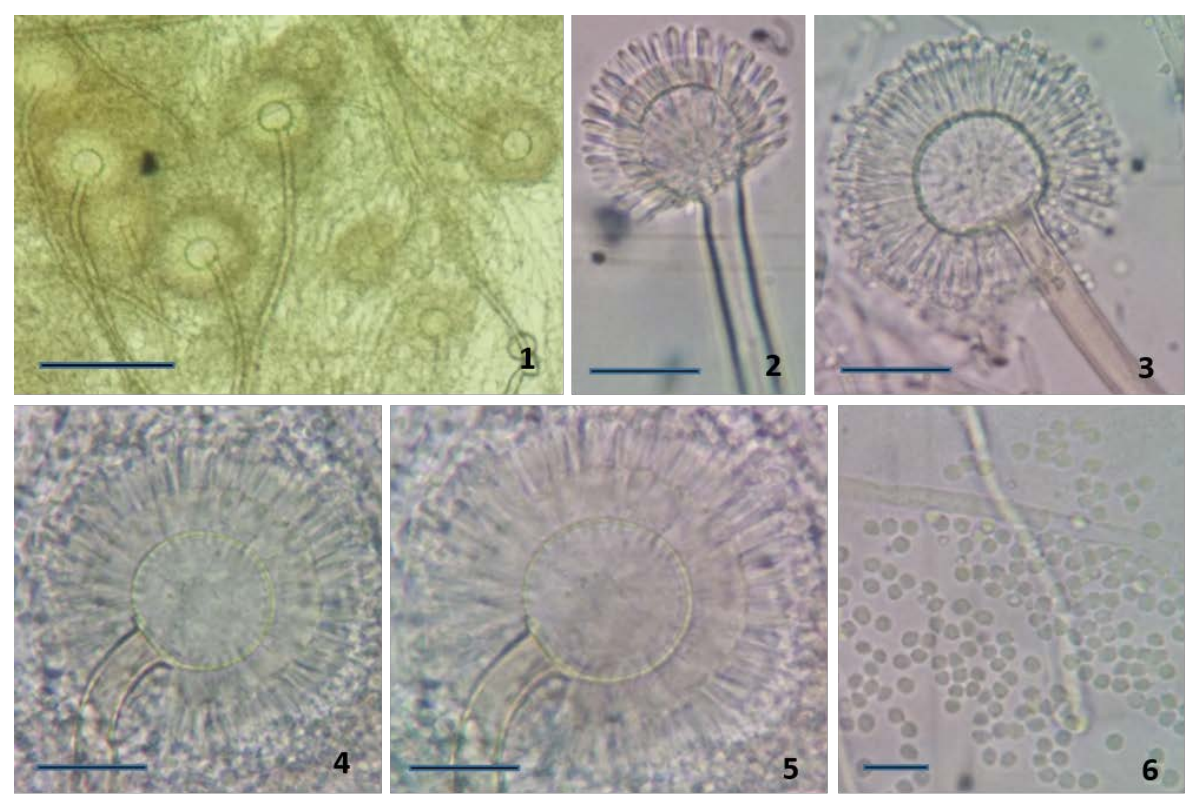

Fig. 3 - Microscopic features of Aspergillus gaarensis AUMC 11046. 1-5 conidial heads and conidiophores. 6 conidia. Scale bars $1=100 \mu \mathrm{m}$. $2-5=20 \mu \mathrm{m} .6=10 \mu \mathrm{m}$.
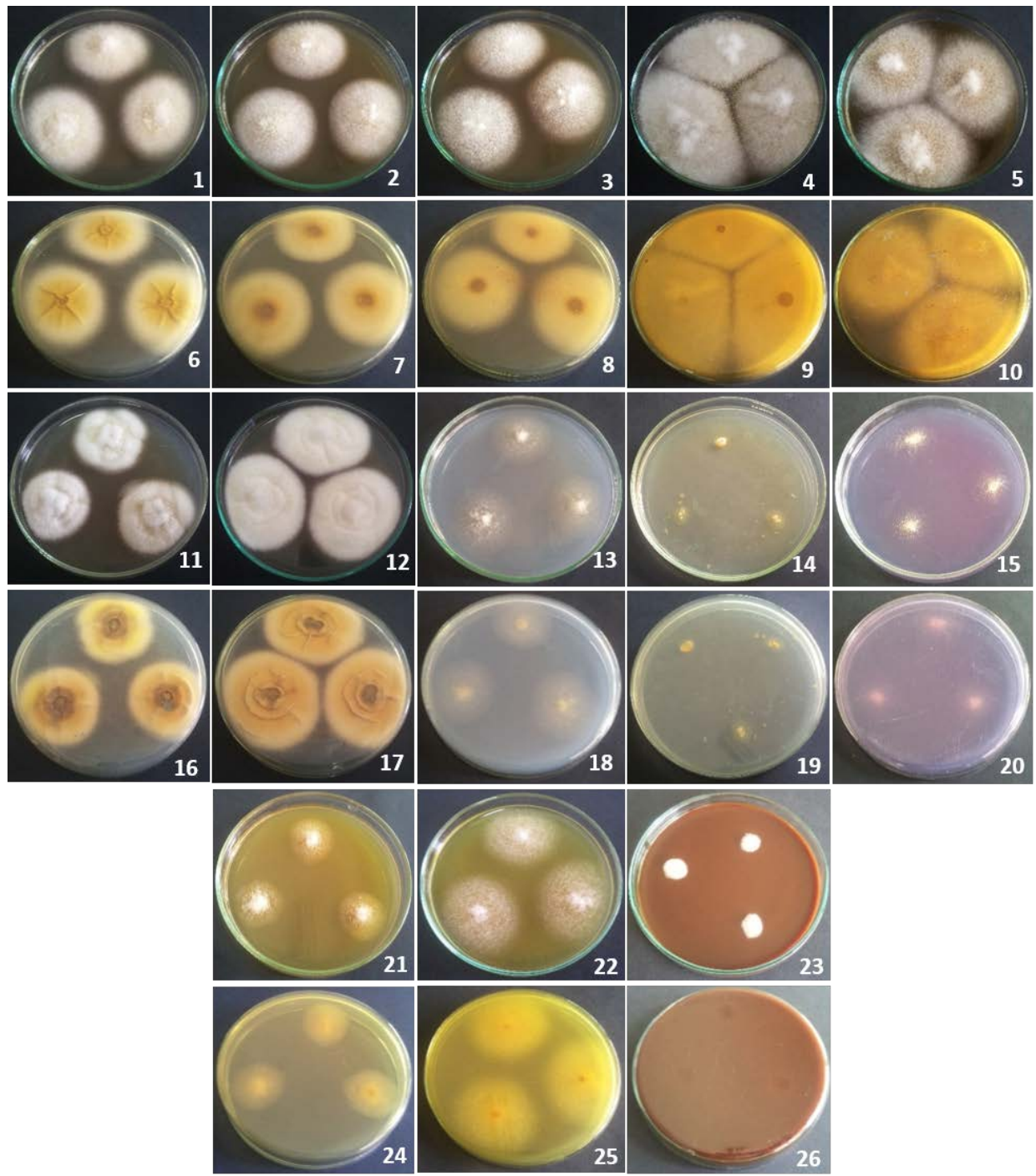

Fig. 4 - Cultural features of Aspergillus gaarensis AUMC 11046. 1-5 colonies on YES, MEA, MEAbl, M20S, M40S. 5-10 reverse on YES, MEA, MEAbl, M20S, M40S. 11-15 colonies on 
CYA, CY20S, Cz, CYA37, CREA. 16-20 reverse on CYA, CY20S, Cz, CYA37, CREA. 21-23 colonies on urea, mannitol, TAN. 24-26 reverse on urea, mannitol, TAN.

Table 1 The colony diameter of A. gaarensis AUMC 11046 on the other growth media after 7 days at $25^{\circ} \mathrm{C}$.

\begin{tabular}{lclc}
\hline \multicolumn{1}{c}{ Medium } & Diameter $(\mathbf{m m})$ & \multicolumn{1}{c}{ Medium } & Diameter $(\mathbf{m m})$ \\
\hline $\mathrm{Cz}$ & $3.0-3.5$ & MEAbl & $4.0-5.0$ \\
Yes & $4.0-5.4$ & CREA (no acid) & $2.8-3.5$ \\
$\mathrm{CY}_{20} \mathrm{~S}$ & $4.5-6.0$ & Urea (negative) & $2.5-3.0$ \\
$\mathrm{CYA37}$ & $0.4-0.7$ & Mannitol (negative) & $4.0-5.0$ \\
$\mathrm{M}_{20} \mathrm{~S}$ & $4.2-7.5$ & Tannic acid & $1.0-1.3$ \\
$\mathrm{M}_{40} \mathrm{~S}$ & $4.0-7.0$ & & \\
\hline
\end{tabular}

Aspergillus gaarensis can be distinguished from A. ochraceopetaliformis and A. pulvericola by the absence of sclerotia which are produced in A. pulvericola while A. ochraceopetaliformis produces reddish-brown sclerotia-like structures, and by smaller metulae (8-13 $\mu \mathrm{m})$ which reach up to $28 \mu \mathrm{m}$ in A. ochraceopetaliformis and up to $16.5 \mu \mathrm{m}$ in A. pulvericola (Table 2). Moreover, A. ochraceopetaliformis colony appearance is typically dominated by white mycelia which masks the dull yellow to olive brown to brown conidia, a colony colour not observed in A. gaarensis or other species in the section. The new species can be also differentiated from A. insulicola by its yellowish-white to pale yellow sporulation on MEA while A. insulicola produces light orange to greyish orange spores and rough-walled conidiophores.

Table 2 Morphological characteristics of A. gaarensis AUMC 11046 compared with those of the most similar species in section Circumdati on MEA after 7 days at $25^{\circ} \mathrm{C}$.

\begin{tabular}{|l|l|l|l|l|}
\hline $\begin{array}{l}\text { Morphological } \\
\text { features }\end{array}$ & A. gaarensis & A. ochraceopetaliformis & A. pulvericola & A. insulicola \\
\hline Sporulation & $\begin{array}{l}\text { Yellowish- } \\
\text { white to pale } \\
\text { yellow }\end{array}$ & $\begin{array}{l}\text { Dull yellow to olive } \\
\text { brown to brown }\end{array}$ & Yellowish white & $\begin{array}{l}\text { Light orange to } \\
\text { greyish-orange }\end{array}$ \\
\hline Sclerotia & Absent & $\begin{array}{l}\text { Sclerotia-like structures } \\
\text { sparsely produced in } \\
\text { some isolates, reddish } \\
\text { brown, 350-650 } \mu \mathrm{m}\end{array}$ & $\begin{array}{l}\text { Sometimes present, } \\
\text { white to cream, 250- } \\
510 \mu \mathrm{m} .\end{array}$ & Absent \\
\hline Conidiophores & $\begin{array}{l}\text { Pale brown to } \\
\text { brown, rough, } \\
200-600 \times 5-8 \\
\mu \mathrm{m}\end{array}$ & $\begin{array}{l}\text { Hyaline to yellow to } \\
\text { brown, rough walled, } \\
260-1300 \times 8-10 \mu \mathrm{m}\end{array}$ & $\begin{array}{l}\text { Hyaline to brown, } \\
\text { rough, 190-1000 } \times \\
5-9 \mu \mathrm{m}\end{array}$ & $\begin{array}{l}\text { Hyaline to yellow to } \\
\text { brown, rough } \\
\text { walled, 250-600 } \\
6-8.5 \mu \mathrm{m}\end{array}$ \\
\hline Vesicles & $\begin{array}{l}\text { Globose, 20- } \\
40 \mu \mathrm{m}\end{array}$ & $\begin{array}{l}\text { Globose to pyriform, 25- } \\
45 \mu \mathrm{m}\end{array}$ & Globose, 15-53 $\mu \mathrm{m}$ & $\begin{array}{l}\text { Vesicles globose, } \\
15-30 \mu \mathrm{m}\end{array}$ \\
\hline Metulae & $8-13 \mu \mathrm{m}$ & $10-20(-28) \mu \mathrm{m}$ & $5.5-16.5 \mu \mathrm{m}$ & $7-12 \mu \mathrm{m}$ \\
\hline Conidia & $2.5-3.0 \times 2.5$ & $\begin{array}{l}\text { Globose, smooth, 2-3 } \times \\
2-3 \mu \mathrm{m}\end{array}$ & $\begin{array}{l}\text { Globose, smooth, 2- } \\
3 \times 2-3 \mu \mathrm{m}\end{array}$ & $\begin{array}{l}\text { Globose to } \\
\text { subglobose, } \\
\text { smooth, 2-3 } \times 2-3 \\
\mu \mathrm{m}\end{array}$ \\
\hline
\end{tabular}

\section{Acknowledgement}

Professor Ahmed M. Moharram, Director of the AUMC is greatly appreciated and acknowledged for his kind reviewing the manuscript and helpful advices.

\section{References}

Blakeslee AF. 1915 - Lindner’s roll tube method of separayion culture. Phytopathology 5, 68-69. 
Brayford D, Bridge P. 1989 - Differentiation of Fusarium oxysporum from Fusarium solani by growth and pigmentation on media containing sugar alcohols. Letters in applied microbiology 9, 9-12.

Ciegler A. 1972 - Bioproduction of ochratoxin A and penicillic acid by members of the Aspergillus ochraceus group. Canadian Journal of Microbiology 18, 631-636.

Felsenstein J. 1985 - Confidence limits on phylogenies: an approach using the bootstrap. Evolution 39, 783-791.

Frisvad JC. 1981 - Physiological criteria and mycotoxin production as aids in identification of common asymmetric penicillia. Appl. Environ. Microbiol. 41, 568-579.

Hesseltine C, Vandegraft EE, Fennell DI, Smith ML, Shotwell OL. 1972 - Aspergilli as ochratoxin producers. Mycologia 64, 539-550.

Ismail MA, Moubasher AH, Mohamed RA, Al-Bedak OA. 2017 - Extremophilic fungi and chemical analysis of hypersaline, alkaline lakes of Wadi-El-Natrun, Egypt. Int J Techn Res Sci 1, 345-363.

Klich MA. 2002 - Identification of common Aspergillus species. Centraalbureau voor schimmelcultures.

Kumar S, Stecher G, Li M, Knyaz C, Tamura K. 2018 - MEGA X: molecular evolutionary genetics analysis across computing platforms. Molecular biology and evolution 35, 1547-1549.

Miski M, Davis PJ. 1988 - Microbiologically catalyzed enantio-and diastereoselective oxidation of chrysanthemol stereoisomers to chrysanthemic acids. Appl. Environ. Microbiol. 54, 22682272.

Moubasher AH, Ismail MA, Al-Bedak OA, Mohamed RA. 2019 - Ramophialophora chlamydospora, a new species from an alkaline lake of Wadi-El-Natron, Egypt. Asian Journal of Mycology 2, 110-117.

Paterson R, Bridge P. 1994 - Biochemical techniques for filamentous fungi. CaB International.

Pitt JI. 1979 - The genus Penicillium and its teleomorphic states Eupenicillium and Talaromyces.

Raper KB, Fennell DI. 1965 - The genus Aspergillus.

Robbers JE, Hong S, Tuite J, Carlton W. 1978 - Production of xanthomegnin and viomellein by species of Aspergillus correlated with mycotoxicosis produced in mice. Appl. Environ. Microbiol. 36, 819-823.

Samson RA. 2010 - Food and indoor fungi. CBS-KNAW Fungal Biodiversity Centre.

Samson RA, Visagie CM, Houbraken J, Hong S-B et al. 2014 - Phylogeny, identification and nomenclature of the genus Aspergillus. Studies in mycology 78, 141-173.

Singh K, Sehgal S, Vezina C. 1968 - Large-scale transformation of steroids by fungal spores. Appl. Environ. Microbiol. 16, 393-400.

Stack ME, Mislivec PB. 1978 - Production of xanthomegnin and viomellein by isolates of Aspergillus ochraceus, Penicillium cyclopium, and Penicillium viridicatum. Appl. Environ. Microbiol. 36, 552-554.

Tamura K, Nei M. 1993 - Estimation of the number of nucleotide substitutions in the control region of mitochondrial DNA in humans and chimpanzees. Molecular biology and evolution 10, 512-526.

Thompson JD, Gibson TJ, Plewniak F, Jeanmougin F, Higgins DG. 1997 - The CLUSTAL_X windows interface: flexible strategies for multiple sequence alignment aided by quality analysis tools. Nucleic acids research 25, 4876-4882.

Thrane U. 1986 - Detection of toxigenic Fusarium isolates by thin layer chromatography. Letters in Applied Microbiology 3, 93-96.

Van der Merwe K, Steyn P, Fourie L, Scott DB, Theron J. 1965 - Ochratoxin A, a toxic metabolite produced by Aspergillus ochraceus Wilh. Nature 205, 1112.

White TJ, Bruns T, Lee S, Taylor J. 1990 - Amplification and direct sequencing of fungal ribosomal RNA genes for phylogenetics. PCR protocols: a guide to methods and applications 18, 315-322. 